UDK: $28-43(=163.4 * 3)$

Izvorni naučni rad

Primljeno: 16.03.2019.

Prihvaćeno za štampu: 31.5.2019.

dr.sci. Muharem Štulanović, redovni profesor

Univerzitet u Bihaću

Islamski pedagoški fakultet

ebuseba@hotmail.com

\title{
NEKE DILEME OKO TRADICIJE I PREVOĐENJA “ZASTARJELIH” PITANJA
}

\section{Sažetak}

Dva pitanja u proučavanju kauzaliteta vjere i tradicije u identitetu Bošnjaka mogu se shvatiti kao dileme interesantne za praktičnu primjenu $i$ to:

- I - običajni tretman šartova islama,

- II - opravdanost prevodenja nekih klasičnih, "prevazidenih", pravnih pitanja.

U proučavanju evolutivne primjene islama na našim prostorima, inicira se više puta kao dilema, običaj da imami prilikom vjenčavanja, kako bi utvrdili vjerski kredibilitet, mladence propituju o „vjerskim šartovima“, tradicionalno sistematiziranim u grupu od "trideset i tri šarta", koje moraju znati i navest pred imamom, kao šart vjenčavanja.

$U$ ovom radu nudi se odgovor zašto $i$ zbog čega baš takav običaj koji se ustalio $u$ vidu samo tih trideset $i$ tri šarta, u koje su naveli islamske $i$ imanske šarte ili ruknove, odnosno samo supsidijarne vezane za namaz, njegove uvjete i čistoću, taharet (gusul, abdest, tejemmum), izostavljajući sve drugo vezano za pojašnjavajuće „šartove“ zekata, posta, hadždža itd.?!

Hipotetički, dat je odgovor kroz tri mogućnosti i obrazloženja:

1. simplificirano pojednostavljeno objašnjenje nametnuto u socijalističkom sistemu da je vjera personalnog, „kućnog“, ličnog a ne druśtvenog karaktera;

2. stav da je namaz centralni rukn koji se razlikuje od ostalih; $i$ 
3. činjenica dijalektičke, evolutivne, islamske prakse transformisane u jednom vremenu i prostoru.

Što se tiče prijevoda nekih vremenski "prevazidenih" pitanja kao što su pravni propisi ropstva i sl. iz starih klasičnih zbornika pa tako i drugog toma Tuhfe, poznatog klasičnog zbornika iz hanefijskog mezheba, kojeg karakterišu, većim dijelom, propisi koji možda nemaju aktualnu praktično-pravnu vrijednost za današnje vrijeme, ali su svjedočanstvo vremena u kojem se islamski šerijatskopravni sistem - za onoga ko historijski komparira razlicite pravne sisteme dokazao kao nedostižan u pravnom i intelektualnom smislu.

Ključne riječi: Običaj, u’rf, tradicija, dijalektička, evolutivna primjena vjere, ruknovi islama, temelji islama, šartovi islama, prevodenja pravnih izvora, ropstvo, praktično-pravni propisi.

\section{Uvod}

Baveći se proučavanjem kauzaliteta vjere i tradicije u identitetu Bošnjak te i U'rfa kao izvora Šerijata na našim prostorima, kroz obimno istraživanje i knjigu, ali i kroz doktorsku disertaciju na Pravnom fakultetu, jedno pitanje ostalo nam je čitavo vrijeme interesantno, inicirano na hutbi više puta kao dilema i od jednog starog, iskusnog imama iz socijalističko - komunističkog sistema. Tu dilemu smo prezentirali poznatim imamima iz tog vremena i sistema, bivšim vjersko-prosvjetnim referentima iz tog razdoblja istorijata IZ, želeći dobiti neko razložno objašnjenje, ali do sada nismo pronašli zadovoljavajući, sistemski, institucionalni odgovor.

Radi se o tome da su neki imami prilikom vjenčavanja, da bi utvrdili vjerski kredibilitet, mladence propitivali, običajno, o ,vjerskim šartovima“, tradicionalno sistematiziranim u grupu od ,trideset i tri šarta“, koje je posebno ženik, morao znati i izbiflati pred imamom kao šart vjenčavanja.

Dakle, dilema je bila, zašto i zbog čega baš takav običaj koji se „brine“ o samo tih trideset $i$ tri šarta, $u$ koje su naveli islamske $i$ imanske šarte ili ruknove, zatim samo one vezane za namaz, njegove uvjete i čistoću, taharet (gusul, abdest, tejemmum), izostavljajući sve drugo vezano za

\footnotetext{
${ }_{1}^{1}$ Muhammed b. Ahmed, Ebu bekr A'laud-din es-Semerkandi, Tuhfetul-fukaha (darulkutubil-i'lmijje, Bejrut, 1414/1994.)
} 
pojašnjavajuće „šartove“ zekata, posta, hadždža itd.?! Kao da su ti glavni temelji i ruknovi islama, osim namaza, imali sporedan, supsidijaran značaj, iako bi takvo predstavljanje narušavalo vjerodostojno vjerovanje i doktrinu islama.

Drugo pitanje predstavlja problem prevođenja klasičnih djela i pravnih zbornika koji su sadržavali i mnogo toga što se moglo smatrati prevaziđenim ili specifičnim za određeno vremensko razdoblje. Tako i drugi tom Tuhfetul-fukahai, karakterišu, većim dijelom, propisi koji možda nemaju aktualnu praktično-pravnu vrijednost za današnje vrijeme, ali su svjedočanstvo vremena u kojem se islamski šerijatskopravni sistem - za onoga ko historijski komparira različite pravne sisteme - dokazao kao nedostižan u pravnom i intelektualnom smislu. Iako se radi o vremenu i epohi robovlasničkih društvenih odnosa koji su sa aspekta današnjih društvenih shvatanja neprihvatljivi, praktičnopravni propisi koji reguliraju neke aspekte te legislative vrhunac su pravne regulative u smislu pravnih vrijednosti, bazirani na prirodnom pravu, humanizmu, altruizmu, pravdi, pravičnosti i moralu. Šrijatski, pravni sistem, s pravom pretenduje da bude pozitivni pravni sistem do Sudnjeg dana, prema tome ima vrijednosti za sve faze ljudske historije pa i robovlasničko doba, kao i za budućnost do Sudnjeg dana, kroz fleksibilne, adaptivne propise utemeljene idžtihadom iz Božanskih izvora i Tradicije.

U pokušaju elaboracije ovih pitanja potrebno je za rasvjetljavanje i izučavanje upotrijebiti metodološki pluralizam što pretpostavlja upotrebu historijske, sociološke, filozofske, aksiološke, pravne, te metode teorijske analize i komparativni metod, s jedne strane, kao i upotrebu islamske historijske metode pamćenja i sjećanja (metod seneda $\mathrm{i}$ isnada) te metodologije islamske jurisprudencije (usuli fikh) $\mathrm{u}$ ocjeni, analizi i kvalifikaciji tekstova i njegovih hermeneutičkih značenja, s druge strane. Primjenjujući spomenuti metodološki pluralizam u izučavanju i osvjetljavanju fenomena ove teme koristićemo svaku od spomenutih metoda u domenu njenih određenih spoznajnih granica i mogućnosti.

\section{Dilema oko šartova islama}

Imami su prilikom vjenčavanja, ranije, propitivali mladence o „vjerskim šartovima“, tradicionalno sistematiziranim u ,trideset i tri 
šarta“, koje su mladenci, morali znati i navesti pred imamom kao šart vjenčavanja.

Postavlja se pitanje, zašto i zbog čega je ustrojen baš takav običaj i tradicija o samo tih trideset $\mathrm{i}$ tri šarta, uključujući islamske i imanske šarte ili ruknove, zatim samo šartove vezane za namaz, njegove uvjete i čistoću, taharet (gusul, abdest, tejemmum), izostavljajući sve drugo vezano za zekat, post, hadždž itd.?! Kao da su ti glavni temelji i ruknovi islama, osim namaza, imali sporedan, supsidijaran značaj, iako bi takvo predstavljanje narušavalo vjerodostojno vjerovanje i doktrinu islama.

Hipotetički su tri mogućnosti odgovora na ovu dilemu:

\section{Simplificirano pojednostavljeno objašnjenje nametnuto u socijalističkom sistemu da je vjera personalna, „kućna“, lična a ne društvana stvar}

Dakle, radi se o praktičnom, svakodnevnom, primjenjenom islamu, to je najbitnije i to se sačuvalo kao običaj ličnog, personalnog karaktera, dok drugi segmenti nisu tako svakodnevni i bitni..., odnosno, islam je sveden na tu personalnu, kućnu dimenziju koja u socijalističkom političko-ekonomskom sistemu ne bi trebala da dublje zadire $u$ ekonomska, društvena, i druga pitanja. Iz tog razloga spomenuti su samo ovi ,praktični““ šarti.

\section{Obrazloženje da je namaz centralni rukn za razliku od ostalih}

Islam se temelji na pet temelja (ruknovi) bitnih, sastavnih dijelova bez kojih nema zgrade islama. Svi ostali ruknovi, izuzev namaza, ne moraju uvijek i u svakoj situaciji da se nađu u praksi svakog muslimana, jer ima raznih kategorija muslimana, bogatih i siromašnih. Siromašni muslimani koji nisu u mogućnosti ne moraju obavljati hadž, nisu obavezni dijeliti zekat i sl. dok bolesni, iznemogli, putnici i slično ne moraju u tim (ne)prilikama postiti, itd. Dakle, spomenuti ruknovi islama izvršavaju se samo kad se ispune uvjeti za njih i zavise od stanja svakog pojedinog adresata (obveznik). Oni koji nisu u mogućnosti i ne ispunjavaju potrebne uvjete nekih islamskih ruknova, oni imaju šerijatsko opravdanje za njihovo neizvršavanje i ostavljanje.

Međutim, uloga namaza i njegova specifičnost $u$ islamu je takva da svakog vjernika muslimana, uvijek, u svakoj prilici identifikuje i 
determinira kao vjernika, praktičara, što ne posjeduje kao specifičnost ni jedan drugi rukn i stub islama. Faktički, namaz je vid lične iskaznice muslimana kojom on dokazuje vjernički identitet, uvijek, u svakoj prilici i situaciji i obavezno pet puta na dan; kada je kod kuće ili na putu, u miru ili ratu, kada je slobodan ili zaposlen, zdrav ili bolestan uz olakšice za obavljanje namaza u raznim (ne)prilikama, kao što je skraćivanje četverorekatnih namaza na dvorekatne za putnika, mesh po mestvama i čarapama kod uzimanja abdesta, tejemmum u slučaju da nema vode ili njenoj potrebi za piće i sl. Namaz se ne smije ostaviti i ne klanjati, jer to dovodi u pitanje vjeru. U Kur'anu se kaže:

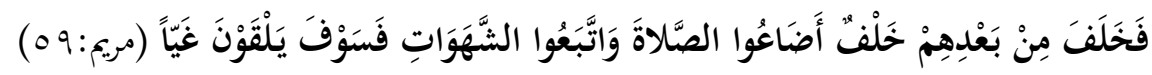
A njih smijeniše zli potomci, koji namaz upropastiše (napustiše) $i$ za požudama pođoše; oni će sigurno zlo proći. /19:59/

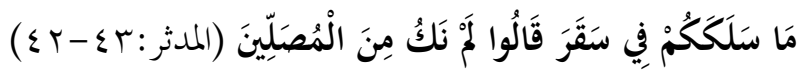

Šta vas je dovelo u Sekar (Džehennem)? Rekoše: „Klanjači nismo bili..."/74:42-43/

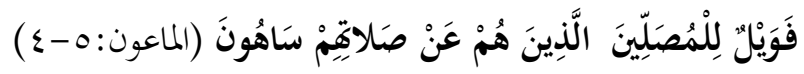

Teško onima koji, kad namaz obavljaju, molitvu svoju kako treba ne izvršavaju. /107:4-5/

\section{Dijalektička, evolutivna praksa transformisanog islama}

U našim istraživanjima tradicije susreli smo se sa islamskim običajima, adetima, u'rfom, transformisanim vidom šerijatske prakse, koja je vremenom evoluirala $u$ islamsku tradiciju gdje su islamske, šerijatske norme u svom trodimenzionalnom značenju, kao vjerske, moralne i pravne, personalnom ili društvenom primjenom i praksom, redigovane $\mathrm{u}$ krajnjoj konsekvenci dijalektičkog evolutivnog historijskog hoda $\mathrm{u}$ vjersko, moralno pravo ili kodeks vjerske etike.

Ovaj proces smo pokušali osvijetliti na znanstveni način, valorizirati i analizirati vezu te transformacije islamske prakse, koja se evolutivno redigovala $u$ tradiciju, sa nastajanjem i izgradnjom specifičnog identiteta Bošnjaka. Tražili smo vezu islama kao vjerskog sistema življenja i islamske prakse sa nastajanjem islamske tradicije koja je utkana u identitet Bošnjaka. 
Islam i njegov društvenopolitički i pravni sistem imao je u svojoj primjeni evolutivni put dijalektičkih promjena pa se na osnovu toga pretpostavlja da je u skoroj prošlosti socijalističko-komunističkog sistema došao do svoje najniže praktične razine $i$ konačne transformacije iz potpunog kompletnog sistema življenja u primjenjeno vjersko moralno pravo ili kodeks vjerske etike.

Kao primjenjeni sistem i življena religija u svim aspektima života, islam, inače, pretenduje da bude praktični sistem ponašanja ljudi do Sudnjeg dana zbog činjenice da je islam pečat objavljenim vjerama a Muhammed, a.s., pečat poslanicima zbog čega je neminovno da mora posjedovati potrebnu fleksibilnost i adaptivnost. Otkrivanje i detektiranje pravne snage i stepena vjerske prakse, istorijski u određenim vremenskim periodima, daje objašnjenje fleksibilnosti i adaptivnosti islama $\mathrm{u}$ opstanku praktično; ako ne potpuno kao autentičnog, kompletnog sistema, a ono makar djelimično kroz običajno pravo ('urf) i adete; ako ne kroz sudstvo i pozitivne zakone koji se primjenjuju na državnom nivou, a ono makar kroz specifične šerijatske sudove ograničenih ingerencija na neki personalni status i ulogu, ili kroz običajnu vjersku praksu, i na koncu makar i najnižim stepenom primjene kroz razne vidove kulturološkog i civilizacijskog djelovanja: narodnu poeziju, narodne umotvorine, folklor i sl., jer $\mathrm{u}$ svemu tome islam čuva i krije svoj prepoznatljivi kôd ili nukleus. U ovim činjenicama leži objašnjenje istorijske, dijalektičke, evolutivne, primjene islama, njegove transformacije $u$ tradiciju $i$ konačno formiranje islamskog identiteta Bošnjaka kao i njihove međusobne korelacijske veze.

Općepoznata je činjenica da se u našem bošnjačkom miljeu islam često poistovjećuje samo sa tradicijom i običajima, ili možda čak samo sa običajnom obredno-sakralnom praksom hanefijskog mezheba, ili u krajnjoj konsekvenci, sa njegovom zatečenom evolutivnom praksom, čime se, naravno, devalvira njegova autentičnost kojoj se može vratiti i na koju se može referirati putem upoznavanja sa neprevaziđenom kulturom pamćenja i sjećanja $u$ istoriji islama.

Islamska praksa se temelji na tradicionalnim izvorima Kur'ana i sunneta iz kojih se crpe obaveze ibadata (obredoslovlje) u kojem postoji tzv. te'abbud ili kultno, doktrinarno prihvatanje šerijatskih normi koje se najviše primjenjuju u praktičnom životu muslimana, a njeni propisi 
ostaju pozitivni propisi koji se praktično poštuju, izvršavaju i primjenjuju dok god se neko ikako računa muslimanom u ideološkopraktičnom smislu. Efikasno, konstantno i sukcesivno prakticiranje obredoslovne grane islama u muslimanskom društvu, kao što su islamski temelji/ruknovi/šarti: šehadet, namaz, post, zekat i hadždž, uslovilo je nastajanje mnogobrojnih islamskih, šerijatskih običaja ili dovelo do nastajanje islamske tradicije kroz dugotrajnu vjekovnu praksu zabilježenu u narodnom usmenom ili pismenom stvaralaštvu.

Dakle islam je bio izvor običajnom ponašanju, odnosno, običaj je u ovim slučajevima refleksija ili sredstvo čuvanja određenih vjerskih obaveza, normi u praksi nakon gubitka islamske vlasti gdje se kroz moralno pravo i ponašanje, te etičko vjerski kodeks redigovao $u$ adete $i$ kao takav uspio sačuvati od potpunog nestajanja iz prakse. Naravno, nije to bio slučaj sa kompletnim sistemom islama, tako da je fokus bio na pitanjima koja su običajno i tradicijski sačuvana i memorisana $u$ kolektivnoj svijesti pamćenja i sjećanja, najčešće ona koja su bila najbliža personalnoj praksi svih članova društva.

$\mathrm{Na}$ primjeru izučavanja islamske tradicije Bošnjaka, islam, pored stalnih, nepromjenljivih, fiksiranih propisa, koji su malobrojni i zauzimaju mali dio regulative, posjeduje svojstvo stalnog, aktualnog, savremenog, pravnog pozitiviteta implementirajući se u aktualnim društvenim promjenama i prateći na takav način razvoj društvenih odnosa, tradicije i običaja u kojima se održava praktično u nekom tradicijskom vidu koji kreira identitet prakse u svom vremenu.

\section{-II-Dilema oko prevođenja nekih klasičnih, „prevaziđenih“, pravnih pitanja}

Drugi tom Tuhfe, karakterišu, propisi koji možda nemaju aktualnu praktičnopravnu vrijednost, ali su svjedočanstvo vremena u kojem se islamski šerijatskopravni sistem dokazao kao nedostižan u pravnom i intelektualnom smislu. Iako se radi o vremenu i epohi robovlasničkih društvenih odnosa koji su sa aspekta današnjih društvenih shvatanja neprihvatljivi, praktičnopravni propisi koji reguliraju neke aspekte te legislative vrhunac su pravne regulative u smislu pravnih vrijednosti, bazirani na prirodnom pravu, humanizmu, altruizmu, pravdi, pravičnosti i moralu. Ne treba pod krinkom licemjera, bojazni, ili ljudske slabosti, iz kompleksa i sličnih pobuda, izbjegavati govor o 
nekom od aspekata islama, izbjegavajući ono što u očima islamofoba i mrzitelja islama i islamske baštine može biti nedostatak, jer šerijatski pravni sistem, pošto pretenduje da bude pozitivni pravni sistem do Sudnjeg dana, ima vrijednosti za sve faze ljudske historije pa i robovlasničko doba, kao i za budućnost do Sudnjeg dana, kroz fleksibilne, adaptivne propise utemeljene idžtihadom iz Božanskih izvora i Tradicije.

U prvi mah moje primjedbe recenzenta prevodiocu drugog toma Tuhfe bile su da se spominjanje stare valute u vidu srebrenjaka i dinara, te lokalnih mjera, ili propisi oko roblja, uz navođenje praktičnopravnih propisa koji reguliraju tu materiju, jednostavno u prijevodu izostave $\mathrm{i}$ zamijene sa nekim drugim primjerom. Međutim, to bi značilo da se onda gotovo kompletan drugi tom Tuhfe izostavi, što bi bila velika šteta i zabadanje glave u pijesak na sve ono što neprijatelji islama pokušavaju imputirati i iskoristiti kao argument svojih neutemeljenih napada na islam. Robovlasnički društveni odnosi su bili historijska realnost, a islam je i u tom domenu dao, od samog početka, takve revolucionarne humane propise $\mathrm{u}$ historiji pravnih sistema, da bi bila nepopravljiva šteta zaboraviti to vanserijsko pravno apstrahiranje, pravne fikcije i akrobacije $\mathrm{u}$ tom domenu, koje nemaju ravnih $\mathrm{u}$ historiji pravne znanosti.

U ovom tomu govori se o kupoprodaji i nekim drugim pitanjima kroz čiju se regulativu može pratiti hanefijska metoda donošenja praktičnopravnih propisa, posebno upotrebom istihsana i analogije, kao i derivaciju rješenja indukcijom iz rješenja koja je dao Ebu Hanifa, ili trojna elita mezheba, prvenstveno kroz navođenje stavova zabilježenih u temeljnoj, mezhebskoj, pravnoj zbirci izvora Zahirur-rivaja, a onda, ako se radi o nekim pitanjima koja nisu obuhvaćena tim rješenjima spominju se i stavovi Zufera kao i El-Hasen b. Zijada. S druge strane, spominju se, redovno, i stavovi Šafija, posebno ako je on imao stav oprečan hanefijskom mezhebu.

Naravno, primjećuje se, za neke, možda, suhoparna pravna tematika oličena u metodu tefsirskog-tefsilskog, naučnog, pravnog apstrahiranja, što je specifičnost hanefijskih pravnih zbornika sve do pojave Medželle, međutim, mora se priznati da u svemu tome ima izuzetna vrijednost $\mathrm{i}$ pravna baština za naučne istraživače islamske pravne misli, iako je ova metoda u praktičnom smislu predstavljala ogromnu poteškoću 
sudijama-kadijama koji su umjesto kodificiranih zbornika i pravnih paragrafa u suđenju imali takozvani fikh tefsili i tefsiri. Iako su pravni zbornici sređivani i recenzirani po ustaljenim poglavljima i redosljedu, njihova glavna karakteristika bila je jedna nevjerojatna disperzija i nejedinstvo mišljenja kroz nebrojene disputacije i naučna obrazloženja, bez sižeiranih pravnih paragrafa i sažetih zakonskih propisa. Pitanja i problemi iz islamskog fikha objašnjavani su, po pravilu, sa mezhepskog aspekta, različitim mezhepskim stavovima, a u međumezhepskim raspravama i disputacijama, često i suprostavljenim stavovima, tako da je to predstavljalo gotovo nepremostivu teškoću u sudstvu i kod praktične primjene.

Mišljenja koja su dolazila od imama mezheba bila su različite pravne snage, često u zavisnosti od predaja ili autoriteta koji ih bilježe ili prenose. To je najveća i najobimnija pravna baština koju je svijet ikad upoznao, predstavljena u pravnim školama (mezhebima) poznatih učenjaka. Razlaz među ovim pravnim školama bio je, isključivo, pravno-praktične prirode, a ne doktrinarne, vjerske naravi.

Međutim, na kojim je sve problemima kadija ili muftija kada treba donijeti presudu ili dati pravni savjet vidi se iz slijedećih činjenica. Samo, u hanefijskom mezhebu što je vidljivo i u ovom dijelu Tuhfe, a slično je i u ostalim pravnim školama, postoji više vrsta pravnih, mezhepskih mišljenja, o nekom pitanju, u zavisnosti od njihove pravne snage; postoji specifična mezhepska pravna terminologija; poseban način preferiranja mezhepskih stavova i sl.

Hanefijski pravnici, naime, stepenuju mezhepske pravne knjige i zbornike u tri kategorije ${ }^{2}$ :

Mesailul-usul مسائل الأصول (temeljne mes'ele-pitanja) koja se zovu i Zahirur-rivaje ظاهر الرواية (očevidno, jasno egzoterično predanje).

Mesailun-nevadir مسائل النوادر (rariteti, rjetkosti, malobrojna pitanja) jesu mes'ele prenešene od spomenutih mezhepskih učenjaka ali ne u zbirci Zahirur-rivaje ظاهر الرواية, nego u drugim Muhammedovim knjigama kao što su El-Kisanijat, El-Harunijat, El-Džurdžanijat, Er-

\footnotetext{
${ }^{2}$ H.M. Handžić, Kodificiranje šerijatskog prava kod raznih pravnih škola, predgovor u: Tumač šerijatskih propisa (H. Muradbegović), 260.
} 
Rikkijjat, El-Meharidž fil-hijel, Zijadetuz-zijadat koju prenosi Ibni Rustem.

El-vaki'at vel-fetava الواقعات و الفتاوى (pravni događaji i decizije). U ovu kategoriju spadaju pitanja koja su riješili pozni mezhepski mudžtehidi kada su pitani o pojedinim pitanjima za koja nisu postojala mezhepska rješenja njihovih imama ${ }^{3}$.

Ovako su stepenovana mezhepska mišljenja. Ako se mezhepska ulema raziđe po nekom pitanju i ne složi na jedinstveno mezhepsko mišljenje (el-ittifak) onda vrijede posebna i komplikovana pravila preferiranja u mezhebu ${ }^{4}$.

Dakle, ne može se lahko ni zamisliti koju teškoću pretstavlja praktični odabir nekog rješenja, za kadiju ili muftiju, ako nema unutarmezhebskog konsenzusa po određenom pitanju kada mora konsultovati naučne pravne izvore sa možda hiljadama stranica, umjesto određenih, sažetih paragrafa, koji sižeira određeno pravno rješenje.

Nakon ovih opservacija da se vratimo našoj dilemi, da li ima pravne relevantnosti i opravdanja da se prevode stari pravni zbornici koji tretiraju „Zastarjela“ pitanja i legislativu koja nema buduću primjenu?!

Posebna vrijednost drugog toma Tuhfe leži u činjenici da su pravnici mezheba morali kroz njene propise, iako se radi o vremenu koje karakterišu robovlasnički društveni odnosi, revolucionarno pokazati svu vrijednost, ljudskost, moralnost, nedostižnost, božanskog šerijatskopravnog sistema u domenu i takvih propisa, ali baziranih na prirodnom pravu, na temelju nedostižnih normi i izrijeka, hadisa Allahovog Poslanika, s.a.v.s., koji izražavajući brigu za robovima i onima koji su pod nečijom komandom/upravom, naređuje, kao što je zabilježio imam Muslim (br. hadisa: 3138. i br.:3139.):

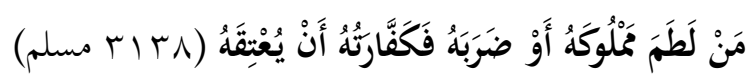

Ko ošamari svoga roba, ili ga udari, iskupljuje se njegovim oslobađanjem.

3 Opširnije u: Muharem Štulanović, Uvod u šerijatsko pravo (fikh) i njegovu metodologiju (usuli fikh), (Bihać, 2002), 44-47.

${ }^{4}$ Ibid: 55-57. 


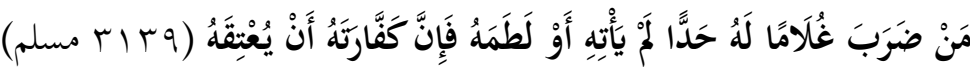

Ko svoga momka (roba) ${ }^{5}$ bespravno izbičuje (fiksirana kazna hadda) ili ga ošamari, iskupljuje se njegovim oslobađanjem.

Ovo su norme na kojima je baziran odnos spram roblja u islamu!!!

Ako analiziramo tekstove Kur'ana koji govore o ropstvu, ne nalazimo norme koje dozvoljavaju porobljavanje slobodnih ljudi. Postoje tekstovi koji pozivaju na oslobađanje roblja, a ne na novo porobljavanje. U praksi Poslanika, a.s., ne nalazimo nove slučajeve porobljavanja nego samo oslobađanje već postojećeg roblja. Ono što se dešavalo poslije Poslanika, a.s., u postupku nekih halifa, može se podvesti pod pravilo „uzajamnog recipročnog postupka” kojim se dozvoljavalo porobljavanje samo ratom i borbom. Međutim, pravna regulativa koja je regulisala te odnose bila je izuzetno humana. U tom smislu želimo navesti nekoliko činjenica:

I pored sužavanja mogućnosti porobljavanja samo na prilike rata i borbe Šerijat propisuje lijep i human postupak prema roblju ${ }^{6}$.

U tom smislu Kur'an kaže:

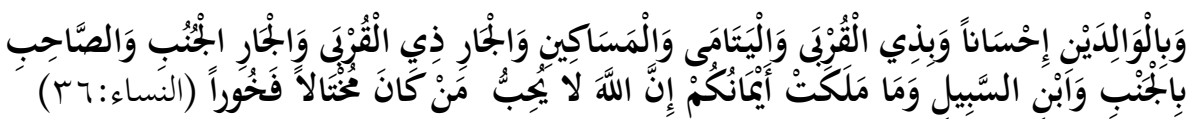

A roditeljima dobročinstvo činite, i rođacima, i siročadi, i siromasima, i komšijama, bližnjim, i komšijama daljnjim, i drugovima, i putnicimanamjernicima, i onima koji su u vašem posjedu (roblje). Allah, zaista, ne voli one koji se ohole i hvališu. (4:36)

${ }^{5}$ Poslanik, a.s., čak nije dozvolio da se upotrebljava izraz rob za roba, naređujući svojim ashabima da ih zovu imenima koja ih neće ponižavati, kao što je došlo u predaji Buharije (2414.) i Muslima:

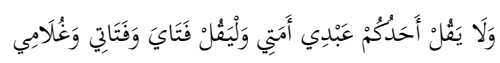
„Neka niko od vas ne zove ,moj rob' nego neka kaže ,moj momak' ili ,moja djevojka'.", ${ }^{6}$ Ebu Bekr El-Džezairi, Minhadžul-muslim, (Put pravog muslimana), (Darul-fikr, 1976), 470-471,

vidi, Sejjid Sabik, Fikhus-sunne (Islamsko pravo u sunnetu), (Darul-fikr, Bejrut, 1977), 3, 88-89. 
Poslanik, a.s., naredio je da se rob oblači kao i njegov gospodar i da jedu istu hranu. Naredio je da se robu ne daju preteški poslovi koje on neće moći izvršiti, inače i gospodar treba da mu fizički pomogne.

Zabranio je da im se čini nasilje, da se ošamare, muče i tuku.

$\mathrm{U}$ islamu je oslobađanje roba djelo koje priskrbljuje Allahovo zadovoljstvo i služi za iskupljenje od teških prijestupa:

1. nehotičnog ubistva ${ }^{7}$,

2. kršenja zakletve ${ }^{8}$,

3. prekršaja zihara ${ }^{9}$ itd.

U Kur'anu se kaže:

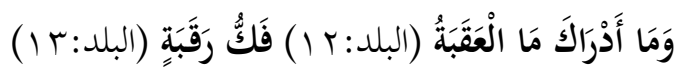

A šta ti misliš: kako se može na blagodatima zahvalan biti? - roba ropstva osloboditi. (90:12-13)

Institucija zekjata, kao vid vjerskog, ekonomskog davanja, ima posebnu kategoriju podjele u svrhu oslobađanja roblja kao što se navodi $u$ kur'anskoj normi najviše pravne snage.

Ovim humanim propisima, koji su, ne treba zaboraviti, bili doneseni prije četrnaest vijekova, ropstvo ipak nije moglo biti potpuno iskorijenjeno zbog okruženja u kojem se nalazila islamska država i islamsko društvo gdje su vladali stabilni robovlasnički odnosi, pa se moralo u međusobnim korelacijskim odnosima uklapati postupajući po pravilu ,uzajamnog recipročnog postupka”.

Druga vrlo bitna stvar koja opravdava uzimanje roblja jeste činjenica da je humanije nekoga staviti u ulogu poštovanog roba, koji se štiti

\footnotetext{
${ }^{7}$ Onaj ko ubije vjernika nehotice-mora osloboditi ropstva jednog roba-vjernika... Kur'an, 4, 92.

${ }^{8}$ Otkup za prekršenu zakletvu je: da deset siromaha običnom hranom kojom hranite čeljad svoju nahranite, ili da ih odjenete, ili da roba ropstva oslobodite. Kur'an, 5, 89.

${ }^{9}$ Oni koji ženama svojim reknu da im nisu dopuštene, kao što im nisu dopuštene majke njihove, a onda odluče da s njima nastave da žive, dužni su, prije nego jedni drugo dodirnu, da jednog roba ropstva oslobode. To vam se naređuje, - a Allah dobro zna ono što vi radite. Kur'an, 58, 3.
} 
pravnim normama izuzetnog humanog sadržaja, nego ga ubiti prilikom ratovanja, vojne pobjede i zarobljavanja. Islam je doktrinarnim tekstovima i normama ostavio nadu za roba u različitim mogućnostima oslobađanja. Zato je alternativa zarobljavanja, umjesto pogubljenja, izuzetno pozitivan, human čin.

Ne smije se zanemariti ni činjenica da je ovo pitanje jedno od onih koje se svakim novim sukobom i ratom nanovo aktualizira, iako smo u 21. stoljeću i nalazimo se u civiliziranoj Evropi. Nažalost čak i na isteku 20. i početkom 21. vijeka osjećaju se posljedice ratova i sukoba. Stanje ljudskih prava je takvo da još uvijek u "savremenom demokratskom društvu" na isteku prve polovine dvadesetog vijeka imamo fakte i surovu realnost holokausta koji se dogodio židovima u Evropi koja slovi kao najnapredniji dio svijeta, da imamo ponovljene genocide nad muslimanima u BiH (Srebrenici i mnogim drugim mjestima) na samom isteku dvadesetog stoljeća u kojem su ubijani njihovi civili, žene i djeca, zarobljenici živi masakrirani, silovani i mučeni na različite načine. Na izmaku 20. stoljeća egzistirali su koncetracioni logori, pred očima javnosti, pred sofisticiranom tehnikom praćenja kojom je međunarodna zajednica mogla to $\mathrm{u}$ tančine pratiti $\mathrm{i}$ snimati. Ostale su stotine masovnih grobnica i stratišta od Srebrenice, do Prijedora i drugih mjesta. A svi vjerski objekti: džamije i mesdžidi porušeni su, vjerski službenici maltretirani, zatvarani u logore, neki zajedno sa porodicom, djecom i ženom zaklani kao što je bio monstruozni slučaj sa našim generacijskim kolegom iz Gazi-Husrev begove medrese u Sarajevu, Ramić Hasib ef., njegovom porodicom, ženom i djecom. Jedini grijeh koji se mogao pripisati žrtvi bio je pripadnost određenoj vjeri.

Baš zbog ove činjenice kojoj smo savremenici, koju smo doživjeli i čije posljedice još uvijek praktično osjećamo moći ćemo razumjeti primjere vrhunskog humanizma i altruizma koje islam gaji prema čovjeku, kao čovjeku ili humanom biću, dajući nenadmašni sistem ponašanja u ratnim prilikama prema neprijatelju i zarobljeniku...

$\mathrm{Na}$ dvije slike, dva događaja ili dva primjera kao paradigmi iz naše burne vjekovne prošlosti možemo jasno ocrtati humanost, altruizam i nenadmašnost postupka muslimanske strane prema čovjeku i njegovoj bezbjednosti, iako se prema muslimanima na ovim prostorima odnosilo na monstruozan način i često postupalo praksom genocida. 
Prva slika je - Srebrenica, mali pitomi gradić-varošica u istočnoj $\mathrm{BiH} \mathrm{u}$ julu 1995., kada u nju ulaze srbočetnici i njihove vojne formacije. Za nekoliko dana brutalnog napada, srpske vojne snage pod komandom generala Ratka Mladića te paravojnih jedinica, uključujući i srbijanske neregularne policijske jedinice koje su prešle na bosansku teritoriju iz Srbije masovno su poubijale više od 8.000 zarobljenih muslimana starijih osoba i dječaka, koji su tražili spas u oblasti pod kontrolom Zaštitnih snaga Ujedinjnih nacija (UNPROFOR). Blizu 25.000 žena, djece i starijih osoba nasilno su deportovani, što pretstavlja najveći čin ratnog zločina u Evropi od Drugog svjetskog rata. I to je samo jedna slika koja se ponavljala u bosanskim kasabama i bosanskim mjestima, tokom perioda 1992-1995.g.

Druga slika, nasuprot ove je Milodraževo polje, 28. maj 1463. U Bosnu ulazi Mehmed II Fatih. Kao pobjednik, je li on tada nemuslimanima, kao što su uradili četiri i pol vijeka kasnije srbočetnici muslimanima, sakupio nemuslimansko življe po Bosni i Hercegovini i počeo sa masakrima i ubistvima, rušenjima i paljevinama; pa da ruši kuće i stanove, crkve i manastire, izvrši genocid i sakralni urbicid, žari i pali kao što su uradili srbočetnici u zadnjem agresorskom ratu na isteku 20. vijeka. $\mathrm{Ne}$, on umjesto toga postupa civilizovano, pravno utemeljeno i izdaje Ahdnamu, sultanski ferman, nakon što je pred njega na Milodraževo polje kod Fojnice izašao predstavnik bosanskih franjevaca fra Anđeo Zvizdović (umro 07. 05. 1498) - koji ga je priznao za novog gospodara Bosne i zamolio da njegovim redovnicima dā vjersku i imovinsku slobodu djelovanja.

A tekst Ahdname u prijevodu prof. Hazima Šabanovića glasi:

On (tj. Bog) je jedini pomoćnik. (Tugra) Mehmed, sin Murad-hanov, vazda pobjedonosan! Zapovijed časnog, uzvišenog sultanskog nišana (znak) i svijetle carske tugre, osvajača svijeta je slijedeće:

Ja, sultan Mehmed-han, stavljam do znanja cijelom svijetu (svom puku i odličnicima) da se prema posjednicima ovog carskog fermana bosanskim redovnicima pojavila moja velika milost, pa zapovijedam slijedeće:

Neka niko spomenutim (kaluđerima) i njihovim crkvama ne pravi smetlje i neka ih niko ne uznemiruje. Neka oni bezbrižno stanuju u mome carstvu. A oni koji su izbjegli (pobjegli i otišli) neka su slobodni 
i sigurni. Neka dođu i neka bez straha stanuju u zemljama moga carstva. Neka se nastane u svojim manastirima i neka niko, ni moje visoko veličanstvo, ni iko od mojih vezira, ni od mojih sluga, ni od mojih podanika, niti iko od stanovnika moga carstva, - ne vrijeđa $i$ ne uznemiruje spomenute. Neka im ne upada i neka ih ne ugrožava $i$ ne vrijeđa ni njih, ni njihove duše (živote), ni njihov imetak, niti njihove crkve. Isto tako neka im je dopušteno da dovedu čovjeka sa strane (iz tuđine) u zemlje moga carstva. Zbog toga spomenutim veledušno podarujem carsku zapovijed $i$ zaklinjem se slijedećim teškim zakletvama: Tako mi Stvoritelja zemlje i neba, koji hrani sva stvorenja, i tako mi sedam mushafa, i tako mi našeg velikog vjerovjesnika (Muhameda), i tako mi sablje koju pašem, - niko se neće protiviti onome što je napisano sve dokle god mi oni budu služili, dok se budu pokoravali i dok budu odani mojoj zapovijedi.

\section{Napisano 28. maja u stanu Milodraž ${ }^{10}$}

Ličnost Mehmeda Fatiha u povijesti je jedinstvena. Iz života i djela Mehmeda Fatiha može se učiti i naučiti ko su i kakvi su muslimani i kakav je odnos muslimana spram ljudskih prava, spram ljudskih života, spram vjerskih sloboda i vjerskih objekata i institucija. Fatihova Ahdnama nije napisana iz straha, nije iznuđena zbog interesa, i nije objavljena iz potrebe za pokazivanjem nego svjesni čin tolerancije koju treba pokazati baš onda kad se ima moć i vlast, kad se ima sablja, kad se ima nepobjedivi asker. Ona je napisana iz uvjerenja da je svako slobodan u svojoj vjeri i svojoj domovini; ona je objavljena da svjedoči o jednom vremenu i jednom čovjeku, koji je bio musliman, koji se Allaha bojao i za kojeg je čovjek bio čovjek, bez obzira što nije bio njegovog uvjerenja i vjere. Zato je Fatihova Ahdnama povijesna vrijednost koja nije mogla biti neprimjećena zato što uvijek koristi

\footnotetext{
${ }^{10}$ U Šabanovićevu prijevodu zakletva:"i tako mi 124000 poslanika” je izostavljena. Iako su o Ahdnami kod nas mnogi pisali (Ć. Truhelka, G. Elezović, S. Kemura, Knežević, K. Gujić, J. Matasović, H. Šabanović i drugi), rahmetli Hazim Šabanovića ipak kaže: "Original je, ... nestao nešto prije 1654. godine, jer je u međuvremenu od 1654. do 1669. nastao onaj primjerak Ahdname za koji se drži da je original i koji se kao takav čuva u muzeju Franjevačkog samostana u Fojnici uokviren pod staklom. Taj primjerak, međutim, nije ništa više nego dosta neuspjela imitacija originala." (Vidi: Hazim Šabanović, Turski dokumenti u Bosni iz druge polovine XV stoljeća, str. 200).
} 
ljudima. Ona je neprolazna vrijednost, u njoj možemo prepoznati razliku između istine i neistine - istine koja traje i neistine koja nestaje u bujici koja nosi otpatke što plivaju na površini povijesti.

Dakle, Ahdnama je praktično sve ono što se desilo muslimanima $u$ ovom genocidnom agresorskom ratu spriječila da se tada prije 440 godina desi nemuslimanima, kršćanima na području $\mathrm{BiH}$. Zbog toga možemo danas pričati o kosmičkoj razlici između Mehmeda II Fatiha i onih koji su u Hagu osuđeni kao ratni zločinci, kao i između države koja izdaje proglas Ahdname sa ovakvim humanim sadržajem, štiteći ga i sprovodeći u praksi sultanskom sabljom, utemeljenjem ljudskih i vjerskih prava i između države ili entiteta koji nikne na genocidu.

Nasuprot svega ovog da navedemo još jedan slučaj iz vremena Allahovog poslanika, s.a.v.s., koji je jedinstven u istoriji postupka prema zarobljenicima. Slučaj koji smo slušali u nebrojenim predavanjima i hutbama, a uz koji se pominje primjer otkupa zarobljenih mušrika Bedra, jedinstven u istoriji čovječanstva. Oni su prešli $500 \mathrm{~km}$. udaljenosti iz Mekke do Medine i brda Bedra, ne iz razloga da bi posjetili svoje rođake koje su prognali iz njihovih kuća i domova u Mekki, nego da bi ih pobili jer su, eto, ostavili njihovu pagansku vjeru, primili islam i preselili u Medinu. Došli su, dakle, da ubiju Muhammeda, a.s., njegove časne drugove-ashabe i zatru islam u korjenu. Radi se o vremenu od prije 14 vjekova kada ljudski život i zarobljenik nisu imali nikakvih vrijednosti, po važećim ratnim običajima $\mathrm{i}$ tradiciji. O tom događaju, nalazimo $\mathrm{u}$ vjerodostojnom izvoru:

- Među zarobljenicima Bedra bilo je i onih koji su pismeni.

Ono što je manje poznato a što one koji se bave obrazovanjem i odgojem posebno interesuje jeste sljedeći navod autora u kojem iznosi tvrdnju:

- Od ensarija u to vrijeme nije bio ni jedan pismeni pojedinac.

I u takvom društvu, prosto je za ne povjerovati, koliko su muslimani vrednovali pismenost i onoga ko poučava, jer autor navodi:

- Pismeni zarobljenik mogao se otkupiti i osloboditi pod uslovom da nauči desetero muslimanske djece pismenosti. Zejd b. Sabit, oficijelni 
pisar Objave, čijom aktivnošću je ona autentično sačuvana do Sudnjeg Dana, tako je naučio pismo u grupi djece ensarija. ${ }^{11}$

Zejd b. Sabit, ovako opismenjen, uzet je kao oficijelni pisar Objave, a poslije je za vrijeme pravednih halifa sakupio Kur'an, u dva maha, kompletirajući ga u jednu autentičnu zbirku, naučnom, provjerenom metodologijom sačuvavši ga do Sudnjeg dana u originalnoj verziji. Time je sigurno prvi i najzaslužniji da bude i uzme učešće u množini ili grupi kojom Uzvišeni Allah čuva Kur'an na vjerodostojan način do Sudnjeg dana. Jer, Uzvišeni Allah je u kur'anskom ajetu sure El-Hidžr uz Sebe spomenuo i množinu koja će čuvati Kur'an:

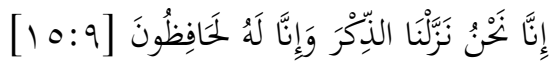

Mi, uistinu, Kur'an objavljujemo i zaista ćemo Mi nad njim bdjeti! (15:9)

Simptomatično je da je Uzvišeni upotrijebio množinu (Mi ćemo, doista) Inna Nahnu a nije rekao (Ja ću) Ene.

Iako je Uzvišeni subjekat i činilac radnje u ovom ajetu, ipak i jezičko i doktrinarno značenje podnosi da se ovdje može podrazumijevati Allahova strana, Njegova ,partija“ (hizb), množina, grupa, tim sastavljen i od vjernika, koji u ovom konkretnom slučaju uče Kur'an i na takav način ga čuvaju.

Uzvišeni govori o „Svome timu, strani, partiji“, kada navodi u ajetima eksplicitno spominjući vjernike u nabrajanju sa Svojim Uzvišenim bićem i Njegovim Poslanikom, a.s.:

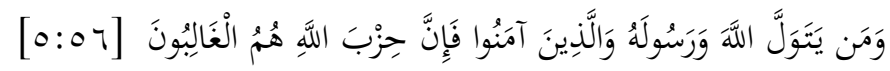

Onaj ko za zaštitnika uzme Allaha i Poslanika Njegova i vjernike - pa, Allahova strana će svakako pobijediti.(5:56)

Prema tome, na Allahovoj strani su vjernici, eksplicitno spomenuti i u drugom ajetu kada ih Uzvišeni opisuje kao „hizbullah“ (Allahov tim, partija):

Abdur-Rahman es-Suhejli, Er-Revdul-unuf fi šerhis-siretin-nebevijjeti, (Darulkutubil-islamijje, 1967.), vidi: El-Mubarekfuri, Zapečaćeni džennetski napitak, (Sarajevo, 1998.), str.: 203. 


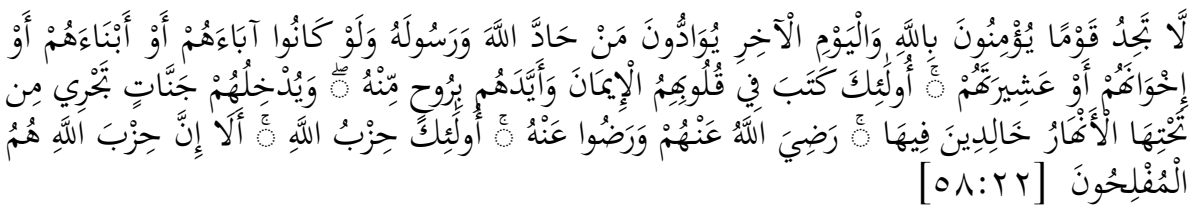

Ne treba da ljudi koji u Allaha i u onaj svijet vjeruju budu u ljubavi sa onima koji se Allahu i Poslaniku Njegovu suprotstavljaju, makar im oni bili očevi njihovi, ili sinovi njihovi, ili braća njihova, ili rođaci njihovi. Njima je On u srca njihova vjerovanje usadio i svjetlom Svojim ih osnažio, i On će ih uvesti u džennetske bašče kroz koje će rijeke teći, da $u$ njima vječno ostanu. Allah je njima zadovoljan, a $i$ oni će biti zadovoljni Njime. Oni su na Allahovoj strani, a onī na Allahovoj strani će, sigurno, uspjeti. (58:22)

Suprotno od toga je đavolova partija (hizbuš-šejtan)

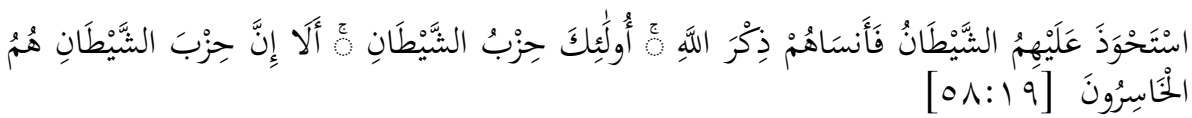

Njima je ovladao šejtan i učinio da zaborave na Allaha. Oni su na šejtanovoj strani, a on̄ na šejtanovoj strani će, sigurno, nastradati. (58:19)

Kao što vjernike stavlja u kontekst svoje partije, Uzvišeni Allah, slično tome nabraja i ulemu u primjeru kada ih stavlja sa Sobom i melekima pa kaže:

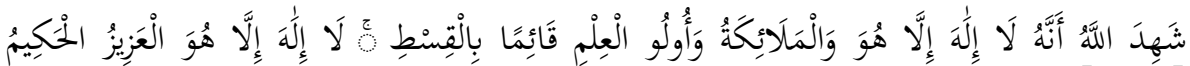
$[r: 1 \wedge]$

Allah svjedoči da nema drugog boga osim Njega - a i meleki i učenii da On postupa pravedno. - Nema boga osim Njega, Silnog i Mudrog! (3:18)

Prema tome, ovdje se misli na ispravno, doktrinarno predstavljanje Uzvišenog Allaha, bez materijalizovanja ili nekog drugog vida skrnavljenja Božijeg bića. Naravno, da nećemo zamisliti ovu grupu kao neki fudbalski ili sportski tim ili klub u kojem je i Uzvišeni a i ljudi sa Njime, fizički, nego se misli na Njegovu stranu, Njegovu istinu, Njegovu volju da nešto bude. Prema tome onaj ko uči Kur'an, logično je, on je na Allahovoj strani. A ono što Uzvišeni hoće, ono i biva, makar se sav svijet i kosmos udružili i protivili. Allahova strana će biti 
pobjednik i sav svijet da se udruži, ne može, ni malo ni puno, doprinijeti Uzvišenom ili mu štetiti!

Dakle, ajet možemo razumijeti kao da je Uzvišeni htio da u ovu množinu/grupu uvede meleke i ljude, sve one koji Kur'an uče, pamte i ne daju da se zaboravi ili iskrivi. Znači, svi koji ga uče i ponavljaju, oni su Allahova ,partija“", Njegova strana, oni su u toj grupi i množini, timu koji čuva Kur'an autentično i ne dozvoljava njegovo iskrivljavanje, u skladu sa riječima Uzvišenog: Mi, uistinu, Kur'an objavljujemo i zaista ćemo Mi nad njim bdjeti!

Dakle, Uzvišeni se ovako izrazio kada govori o čuvanju Kur'ana. Suprotno tome, kada Uzvišeni govori o objavi Tevrata židovskom narodu i o njegovom čuvanju nije rekao ,Mi ćemo ga čuvati...” nego spominje da je traženo od njihovih učenjaka da ga čuvaju, odnosno Uzvišeni eksplicite navodi da je to povjerio njihovim učenjacima $\mathrm{i}$ svećenicima:

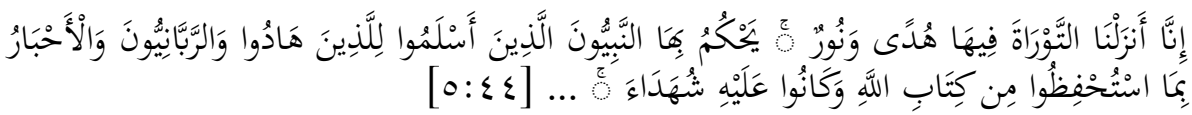

Mi smo objavili Tevrat, $u$ kome je uputstvo i svjetlo. Po njemu su jevrejima sudili vjerovjesnici, koji su bili Allahu poslušni i čestiti ljudi, i učeni, od kojih je traženo da čuvaju Allahovu knjigu, i oni su nad njom bdjeli... (5:43)

Međutim, svjedoci smo činjenice da je jedino Kur'an sačuvan autentično i prenesen do nas originalno, što nije slučaj sa ostalim Božijim objavama kao što suTevrat i Indžil za koje je utvrđeno da nisu sačuvane $u$ originalu.

Prema tome Uzvišeni je htio da u ovu grupu uvede meleke i ljude, sve one koji Kur'an uče, pamte i ne daju da se zaboravi.

A Zejd je, onda, r.a., na vrhu te piramide.

Dakle, oslobađanje roba nemuslimana da za uzvrat pouči muslimansku djecu pismenosti, rezultiralo je takvom vrijednošću koja je uticala na autentično čuvanje zadnje Božije objave što nije bio slučaj ni sa jednom drugom objavom u istorijskom Božijem javljanju plejadi vjerovjesnika, poslanika, opominjača i obveseljivača čiji se broj od 124000 navodi u ispravnom hadisu. 


\section{Zaključak}

Tradicionalni običaj propitivanja mladenaca za vrijeme vjenčavanja o samo trideset i tri šarta, od strane imama koji su vršili obred vjenčanja, zanemarujući druge supsidijarne šarte zekata, posta i hadždža može se objasniti kroz:

- simplificirano, pojednostavljeno objašnjenje nametnuto u socijalističkom sistemu da je vjera personalnog, „kućnog“, ličnog a ne društvenog karaktera;

- stav da je namaz centralni rukn koji se razlikuje od ostalih; i

- činjenicu dijalektičke, evolutivne, islamske prakse transformisane u jednom vremenu i prostoru.

Što se tiče prijevoda nekih vremenski „prevaziđenih“ pitanja kao što su pravni propisi ropstva i sl. iz starih klasičnih zbornika u konkretnom slučaju drugog toma Tuhfe, svjedočanstvo su vremena u kojem se islamski šerijatsko-pravni sistem - za onoga ko historijski komparira različite pravne sisteme - dokazao kao nedostižan u pravnom i intelektualnom smislu.

Naziv „rob“ u šerijatskom pravu samo jezički odgovara terminu roba iz robovlasničkog društvenog poretka i konvencionalnog prava, izvan islamske culture i civilizacije, a s obzirom na vrijednost djela Tuhfe, njegovog drugog toma koji donosi propise iz te oblasti, njegovu ulogu u utemeljenju hanefijskog mezheba kao osnove za komentar možda najvrijednijeg pravnog zbornika u Mezhebu, uopće, Kasanijevog Bedai'a, i s obzirom na ogroman trud prevođenja i rada oko ovog projekta, takvo djelo je vrijedno za objavljivanje kako bi bilo na dohvat ruke budućim pravnim istraživačima i studentima koji će moći komparirati između islamskog i drugih pravnih sistema.

\section{Literatura}

\section{Kur'an i prijevodi Kur'ana}

1. El-Kur'anu-l-kerim, Mushafu-l-Medinetin-Nebevijjeh (Kur'an Časni, medinska verzija Mushafa), (Mudžemme'u-l-melik Fehd, 1405.h.),

2. Korkut Besim, Kur'an s prevodom, (Štamparija kralja Fehda, S. Arabija, Medina, 1412. h.), 
3. The Zekr Project El-Kur'anul-kerim,

4. Quranflash program,

\section{Knjige, brošure i radovi}

5. Abdur-Rahman es-Suhejli, Er-Revdul-unuffi šerhis-siretin-nebevijjeti, (Darul-kutubil-islamijje, 1967.),

6. Ebu Bekr El-Džezairi, Minhadžul-muslim, (Put pravog muslimana), (Darul-fikr, 1976.),

7. El-Mubarekfuri, Zapečaćeni džennetski napitak, (Sarajevo, 1998.),

8. Hangi Antun, Život i običaji muslimana, (Svjetlost, Sarajevo, 1990.),

9. Hangi Antun, Život i običaji muslimana, (Dobra knjiga, 2009.),

10. H.M. Handžić, Kodificiranje šerijatskog prava kod raznih pravnih škola, predgovor u: Tumač šerijatskih propisa (H. Muradbegović),

11. Hazim Šabanović, Turski dokumenti u Bosni iz druge polovine XV stoljeća,),

12. Ibn Džerir et-Taberi, Džami'u-l-bejan fi te 'vili aji-l-Kur'an, (Daru-1Fikr, 1984.),

13. Ibn Hadžer el-'Askalani, Fethul-Bari bišerh Sahihu-l-Buhari, (Darurrejjan lit-turas, Kairo, 1987.),

14. Ibrahim b. Muhammed el-Halebi, Multeka-l-ebhur, (Muesseseturrisale, 1989.),

15. Muhammed b. Ahmed, Ebu bekr A'laud-din es-Semerkandi, Tuhfetulfukaha (darul-kutubil-i'lmijje, Bejrut, 1414/1994.)

16. Muhić Ferid, Islamski identitet Evrope, CNS, Sarajevo 2014.,

17. Sejjid Sabik, Fikhus-sunne, (Daru-l-fikr, Bejrut, 1977.),

18. Sejjid Kutub, Fi zilali-l-Kur'an, (Daruš-šuruk, 1993.),

19. Vehbe Ez-Zuhajli, El-Fikhul-islamijju ve edilletuh (Islamsko pravo i njegovi dokazi), (Darul-fikr, Damask, 1984.),

20. Vojislav Spaić, Nasljednopravni običaji u BiH nakon Austro-Ugarske okupacije", Akademija nauka i umjetnosti BiH, Knjiga XXXII, Odjeljenje društvenih nauka, Knjiga 11, (Sarajevo, 1967.),

21. Sahihul-Buhari, prvo cjelovito izdanje, prijevod: Visoki saudijski komitet za pomoć BiH, Sarajevo, 1430/2009., 


\section{Muharem Štulanović, PhD}

University of Bihac

Islamic pedagogical faculty

ebuseba@hotmail.com

Original scientific article

\section{SOME DILEMMAS ABOUT THE TRADITION AND THE TRANSLATION OF “OBSOLETE” ISSUES}

\section{ABSTRACT}

Two questions in studying the causality of faith and tradition in the identity of Bosniaks can be understood as dilemmas of interest for practical application:

- I - the normal treatment of the Pillars of Islam,

- II - justification of translating some classic, "overstated", legal issues.

In studying the evolutionary application of Islam in our territory, it is initiated several times as a dilemma, the custom of imams at weddings to determine religious credibility, the bride is inquiring about "religious questions" traditionally systematized into a group of "thirty-three pillars", which must to know and to present to the Imam, as a wedding ceremony. In this paper we are offered an answer why and why exactly such a custom that settled in the sight of only those thirty-three articles, in which the Islamic and Immanent articles (pillars) were mentioned, that is, only the auxiliary related to the spread, its conditions and purity, the taharetta (ghusl, wudu, tayammum), leaving everything else related to the clarifying "chaps" of the zekat, fasting, hajj, etc.?!

Hypothetically, the answer is given through three possibilities and explanations:

- a simplified explanation imposed in the socialist system that the faith is a personal, "home", and not a social character;

- the view that the prayer is a central pillar that is different from the others;

- the fact of a dialectical, evolutionary, Islamic practice transformed in one time and space.

Regarding the translation of some time-"over-ridden" issues such as legal regulations of slavery, from the old classical collections and from the second 
volume of Tuhfe, the famous classical collection from the Hanafi school, characterized by, for the most part, regulations that may not have the current practical and legal value for today, but they are a testimony of the times in which the Islamic Shari'a-legal system - for someone who historically compares different legal systems - proves to be unrealistic in legal and intellectual terms.

Keywords: custom, u'rf, tradition, dialectical, evolutionary use of religion, Islamic articles, Islamic foundations, Islamic pillars, translations of legal sources, slavery, practical legal regulations. 


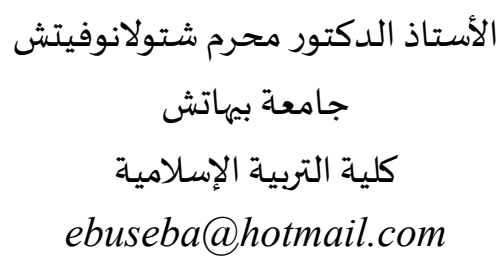

بعض التساؤلات حول التقاليد وترجمة المسـائل الفقهية العتيقة التي عفا عليها الزمان

\section{الخلاصية}

في مجال دراسة العلاقة بين الدين والتقاليد في هوية البوشناق يمكن النظر إلى سؤالين على أنهما من معضلات مهمة للتطبيق العملي وهما: أولا: التعامل العرفي مع شروط الإسلام وأركانها.

ثانيا: مبرر الترجمة لبعض المسائل الفقهية العتيقة التي عفا عليها الزمان.

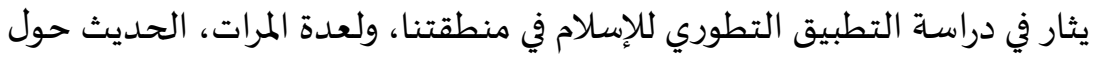
عادة الأئمة أثناء إبرام عقد النكاح أن يطرحوا بعض الأسئلة على العريسين عن شروط

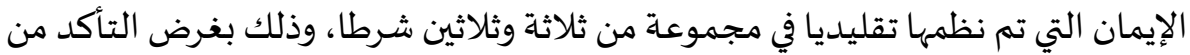
الكفاءة الدينية لدى العريسين، ويتحتم عليهما معرفتها وسردها على مسمع الإمام وهذا تهان كشرط من شروط النكاح.

يقدم هذا البحث إجابة عن سبب ظهور هذه العادة ولماذا استقرت على ثلاثة وثلاثين

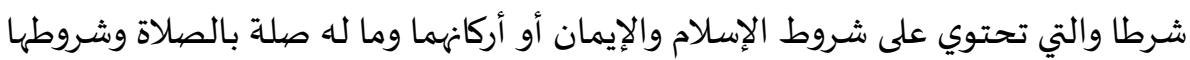

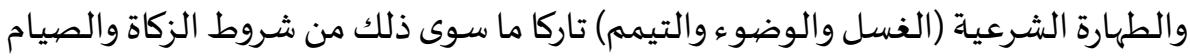

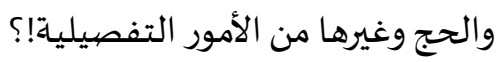
أجيب عن هذا التساؤل بتقديم ثلاثة احتمالات فرضيلة الاهور التفيلية وبياهها:

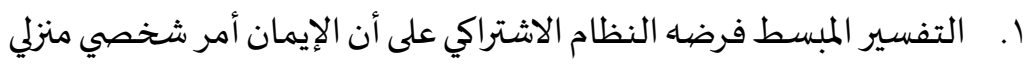
فردي بطبيعتاه وليس اجتماعيا.

r. الرأي القائل بأن الصلاة ركن مركزي يختلف عن غيره من الأركان. r. حقيقة التطبيق العملي المحلي للإسلام التطوري متمثلة في مكان معين مردين وزمان معين. 
أما ترجمة بعض المسائل الفقهية العتيقة التي عفا علهها الزمان مثل المسائل

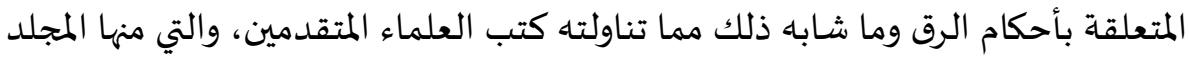

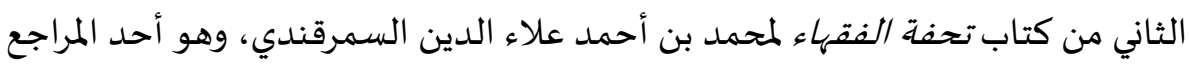

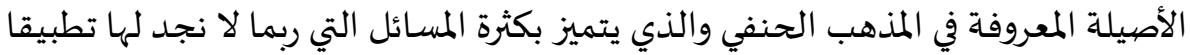

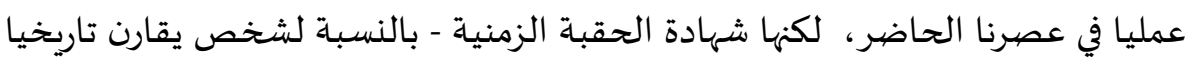

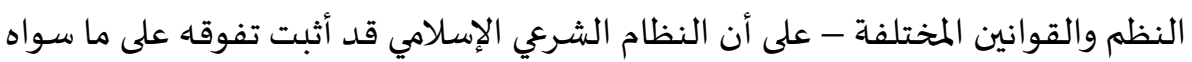
من النظم من الناحية القانونية والفكرياة.

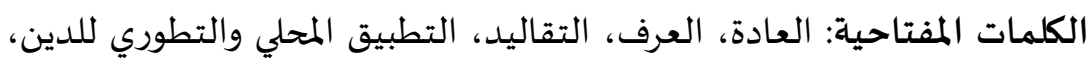

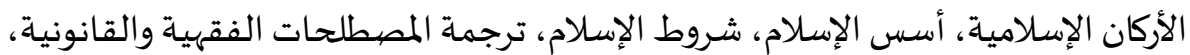
الرق والعبودية، المسائل الفقهية العملية. 